\title{
Sudex cover crops can kill and stunt subsequent tomato, lettuce and broccoli transplants through allelopathy
}

by Charles G. Summers, Jeffrey P. Mitchell,
Timothy S. Prather and James J. Stapleton

\section{Grass cover crops can be harvested} for biomass or used as a surface mulch to reduce erosion, improve soil structure, suppress weeds and conserve moisture. There is concern, however, that such plantings may affect subsequent crops. We studied the effects of sudex, a sorghum hybrid used as a cover crop, on subsequent crops of tomato, broccoli and lettuce started from transplants. Within 3 to 5 days of being transplanted into recently killed sudex, all three crops showed symptoms of phytotoxicity including leaf necrosis, stunting and color changes. There was $50 \%$ to $75 \%$ transplant mortality in all three species. Plant growth and development, as determined by biomass measurements, were also significantly affected. Yields of mature green tomato fruit and marketable broccoli and lettuce heads were reduced significantly. Tomato, broccoli and lettuce should not be transplanted into sudex residue for at least 6 to 8 weeks, or until the residue has been thoroughly leached.

Sudex, a sorghum-sudangrass hybrid, is grown as a cover crop in California to reduce erosion, improve soil structure and suppress weeds. Additionally, sudex (Sorghum bicolor [L.] Moench $\times$ S. sudanense [P.] Staph.) serves as a source of green manure (Weston et al. 1989), forage and silage (Chaudhry et al. 1997). Sorghumsudangrass hybrids, including sudex and collectively known as sudan, are cultivated extensively in the Imperial and San Joaquin valleys. In Imperial County, over 55,000 acres of sudan hay is produced, while in the San Joaquin

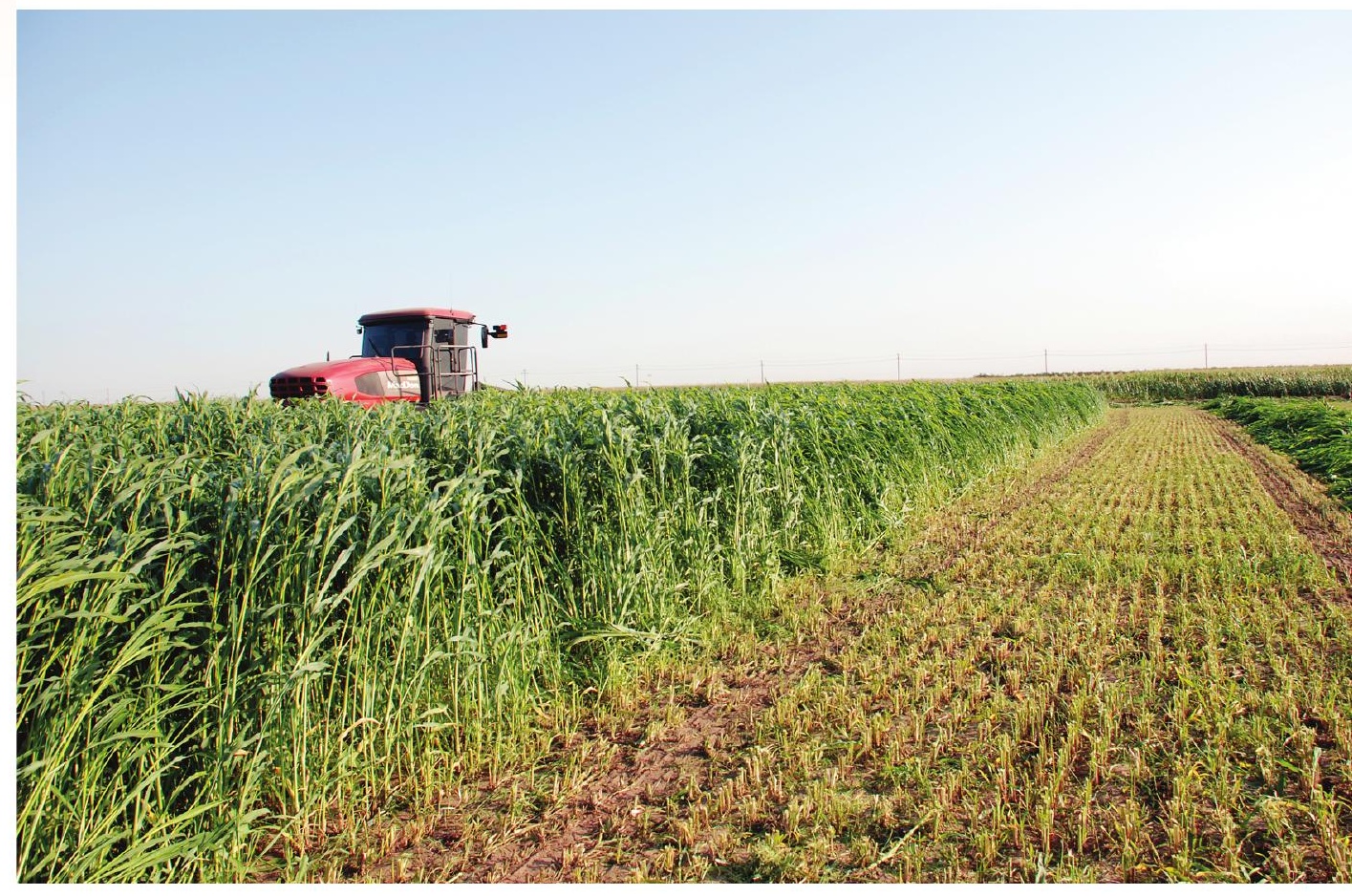

Sudex is a hybrid of sorghum and sudangrass that is grown extensively as a cover crop in the Imperial and San Joaquin valleys to reduce erosion, improve soil structure and suppress weeds. It appears to have allelopathic properties that can damage subsequent vegetable transplants. Above, sudex silage is harvested in Turlock.

Valley an additional 25,000 to 35,000 acres of sudan, mainly for silage and winter forage, are produced annually (Frate 2001). Commonly, tomatoes are planted following late winter/early spring sudex, while broccoli and lettuce are planted after a summer crop of sudex. Sudex grows rapidly, producing large quantities of biomass, and can be harvested several times per season (Finney 2005). Sudex is also a candidate crop for ethanol production from lignocellulose, the woody portion of the plant, along with corn stover (Zea mays L.), switchgrass (Panicum virgatum L.) and Miscanthus spp.

There is, however, a potentially negative aspect of growing sudex as a rotation crop. Certain members of the grass family, including Sorghum spp. in general and sudex in particular, inhibit the emergence or development of nearby or subsequently planted annual and perennial plants (Geneve and Weston 1988). Using sudex extracts, Weston et al. (1989) found a significant reduction in the embryonic root, and elongation of tomato (Lycopersicon esculentum Mill.), garden cress (Lepidium sativum L.), foxtail millet (Setaria italica [L.] Beauv.) and barnyardgrass (Echinochloa crus-galli [L.] Beauv.). This negative impact of one plant on another is called allelopathy when it affects plants of a different species, and autotoxicity when it affects plants of the same species.

Allelochemicals have been isolated from all parts of the sudex plant (Ben-Hammouda et al. 1995a, 1995b; Einhellig and Souza 1992; Forney and Foy 1985). Whereas the impact of such allelochemicals on seedlings is well recognized, their impact on larger transplants is virtually unknown. In 1999, we observed significant mortality in tomato transplants set into a glyphosate-killed sudex mulch. We conducted experiments to determine if sudex was responsible for the transplant mortality, and here report the results of studies in which tomato ('Shady Lady') was transplanted into a 


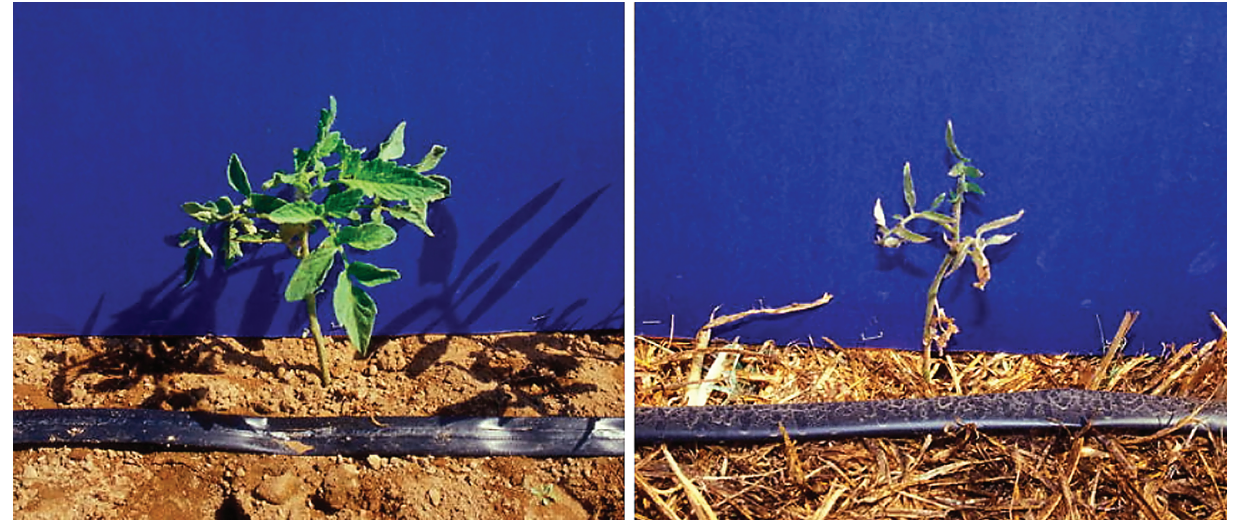

Tomatoes planted too soon after a sudex cover crop can suffer from mortality or yield reductions. Left, a healthy control tomato was planted in fallow soil. Right, a tomato transplant set 20 days after sudex roots and shoots were cut is stunted and shows evidence of necrosis (dead tissue) on the leaf margins.

killed sudex crop during the summer. We also examined the impact of sudex on broccoli (Brassica oleracea var. botrytis L. 'Marathon') and lettuce (Lactuca sativa L. 'Cowboy') crops that would likely be transplanted in the fall following a summer sudex crop.

\section{Transplanting into sudex}

Studies were conducted at the UC Kearney Research and Extension Center in Parlier, on a Hanford fine sandy loam soil. Raised planting beds were formed, and fertilizer (15-15-15, 800 pounds per acre) was broadcast and incorporated.

Sudex treatments. On Aug. 6, 1999, sudex ('Green Grazer V') was drilled at 30 pounds per acre. Irrigation was by surface drip, and liquid fertilizer (17-0-0, 20 pounds per acre) was added through the drip system on Aug. 24 and Sept. 7 and 14. Sudex was shredded on Sept. 24 , when the shoots were about 4.5 feet tall. Regrowth was sprayed 10 days later with $2 \%$ glyphosate (an herbicide) in 20 gallons of water per acre to provide complete coverage. Treatments, arranged in a randomized complete block design with four replications, consisted of: (1) sudex cut, sprayed and left on the soil surface; (2) sudex cut, sprayed and incorporated into the soil with a rototiller; and (3) fallow control, where no sudex was planted and plots were maintained weed-free by occasional rototilling. Sudex biomass (dry) was approximately 4,980 pounds per acre.

On May 1 and July 26, 2000, sudex was drilled into fertilized planting beds as described. The May 1 planting was shredded on June 27 , when the plants were about 6 feet tall, and the July 26 planting was cut and shredded on Sept. 5 , when the plants were about 6.5 feet tall. In both plantings, the sudex stubble was sprayed 10 days after shredding with $2 \%$ glyphosate in 20 gallons of water per acre. Treatments, arranged in a randomized complete block design with six replications, consisted of: (1) shoots + roots sudex cut, sprayed and shoots left on the surface; (2) shoots only - a fallow bed that had not previously been seeded with sudex was covered with cut sudex shoots; (3) roots only - sudex shoots raked off; (4) incorporated - sudex cut, sprayed and then shoots and roots incorporated into the soil; and (5) fallow control. Sudex biomass (dry) was approximately 7,220 pounds per acre.

Vegetable transplants. In 1999, experimental plots were 3 feet long, and we hand-transplanted tomato, broccoli and lettuce (six plants per plot) into the sudex treatments on Oct. 14. While too late for the commercial production of tomatoes, this planting provided an opportunity to evaluate the impact of sudex on tomato transplant mortality. Irrigation was by surface drip, and liquid fertilizer (17-0-0, 20 pounds per acre) was added biweekly.

In 2000, each plot was 15 feet long, and all transplants were set into the sudex treatments in two rows of 10 plants each. Tomato seedlings (20 per plot) were hand-transplanted on July 17, 25 and 31 and Sept. 1, which was 20, 28,36 and 67 days, respectively, after shredding. Broccoli and lettuce (20 per plot) were transplanted on Sept. 26 and Oct. 19, which was 21 and 35 days, re-
TABLE 1. Mean number plants and mean dry weight of tomato, lettuce and broccoli shoots 5 weeks after transplanting, 1999

\begin{tabular}{llll|}
\hline Treatment & Tomato & Lettuce & Broccoli \\
\hline Shoots + roots & \multicolumn{3}{c}{ mean no. plants } \\
Incorporated & $5.0 \mathrm{ab}$ & $0.3 \mathrm{a}$ & $5.0 \mathrm{a}$ \\
Control & $6.0 \mathrm{~b}$ & $4.5 \mathrm{~b}$ & $6.0 \mathrm{~b}$ \\
\hline & mean shoot weight & (oz.lyd. ${ }^{2}$ ) \\
Shoots + roots & $0.033 \mathrm{a}$ & $0.003 \mathrm{a}$ & $0.138 \mathrm{a}$ \\
Incorporated & $0.121 \mathrm{~b}$ & $0.335 \mathrm{~b}$ & $0.697 \mathrm{~b}$ \\
Control & $0.211 \mathrm{c}$ & $0.453 \mathrm{~b}$ & $0.647 \mathrm{~b}$ \\
\hline
\end{tabular}

* Means followed by the same letter(s) are not significantly different according to LSD test, $P \leq 0.05$. spectively, after shredding. Irrigation was by surface drip, and liquid fertilizer (17-0-0, 20 pounds per acre) was added weekly.

In both years, cultural practices were standard for tomato, broccoli and lettuce production in the San Joaquin Valley (Jackson et al. 1996; Le Strange et al. 1996, 2000).

Plant mortality, biomass and yield. In both years, one of the two rows of transplants was selected at random, and plant mortality determinations were made 5 weeks after each group of transplants was set and again at harvest. Plants from the other row were used to determine shoot and root biomass at 5 weeks posttransplanting. To determine biomass, plants were cut at the soil level and the shoots placed in a paper bag. The roots

TABLE 2. Mean number tomato plants per plot 5 weeks after transplanting and at harvest, 2000

\begin{tabular}{|c|c|c|c|c|}
\hline \multirow[b]{2}{*}{ Treatment } & \multicolumn{4}{|c|}{$\begin{array}{l}\text { Days between sudex shredding } \\
\text { and transplanting }\end{array}$} \\
\hline & 20 & 28 & 36 & $67 *$ \\
\hline $\begin{array}{l}5 \text { weeks after } \\
\text { transplant }\end{array}$ & \multicolumn{4}{|c|}{...... mean no. plants. } \\
\hline Shoots + roots & $5.0 \mathrm{a}+$ & $4.0 \mathrm{a}$ & $3.3 a$ & $9.8 a$ \\
\hline Shoots & $7.5 b$ & $5.5 b$ & $4.5 b$ & $0.7 a$ \\
\hline Roots & $8.0 \mathrm{bc}$ & $7.7 \mathrm{bc}$ & $8.8 \mathrm{c}$ & $0.8 a$ \\
\hline Incorporated & $4.0 \mathrm{a}$ & $3.7 a$ & $4.8 b$ & $0.7 a$ \\
\hline Control & $9.7 \mathrm{c}$ & $9.8 \mathrm{c}$ & $9.3 c$ & $0.8 a$ \\
\hline At harvest & \multicolumn{4}{|c|}{....... mean no. plants ...... } \\
\hline Shoots + roots & $4.8 \mathrm{a}$ & $4.0 \mathrm{a}$ & $3.2 \mathrm{a}$ & - \\
\hline Shoots & $5.3 a$ & $4.8 a$ & $4.3 a$ & - \\
\hline Roots & $7.8 b$ & $7.7 b$ & $8.2 \mathrm{~b}$ & - \\
\hline Incorporated & $3.5 a$ & $3.2 \mathrm{a}$ & $4.8 a$ & - \\
\hline Control & $9.0 \mathrm{~b}$ & $9.3 b$ & $9.3 b$ & - \\
\hline \multicolumn{5}{|c|}{$\begin{array}{l}\text { * Plants not taken to harvest. } \\
\text { † Means followed by the same letter(s) are not significantly } \\
\text { different according to LSD test, } P \leq 0.05 \text {. }\end{array}$} \\
\hline
\end{tabular}


were exhumed, washed free of soil and placed in a paper bag. Both shoots and roots were dried at $140^{\circ} \mathrm{F}$ and weighed.

Mature green tomatoes were harvested on Oct. 13, 20 and 27, 2000. Plants from the last tomato planting were not grown to maturity. Marketable broccoli and lettuce heads were harvested from December through January.

Statistical analysis. Data were evaluated by analysis of variance and means separated by LSD (Statistix 8, Tallahassee, FL, 2003).

\section{Survival and mortality}

Tomato. Sudex had a significant impact on tomato transplant survival. Five weeks after transplanting, the maximum tomato mortality was $95 \%$ in 1999 (table 1) and 67\% in 2000 (table 2). In 2000 , the combination of shoot + root material, shoots and soil-incorporated whole plants, resulted in significant mortality $(P \leq 0.05)$ in transplants set 20, 28 and 36 days after shredding (table 2). Roots alone had no significant impact $(P \leq 0.05)$ on plant mortality. By 67 days post-shredding, sudex no longer influenced tomato transplant survival. Plant mortality did not continue past 5 weeks. There was no difference in stand density between counts taken 5 weeks post-transplanting and at harvest. Whatever the causal factor in transplant mortality, it only affected the younger transplants.

Lettuce and broccoli. Fall-planted lettuce and broccoli responded much differently to sudex. In 1999, only plots containing shoot + root material resulted in significant transplant mortality (table 1). In 2000, when transplanted 21 days after shredding, lettuce and broccoli showed a significant increase $(P \leq 0.05)$ in plant mortality in plots containing shoot + root material and shoot material only, but the other treatments (roots only, and soil-incorporated shoots + roots) were not significantly different $(P \leq 0.05)$ from the control (table 3$)$. At 35 days post-shredding, none of the sudex treatments had an impact on transplant mortality (table 3). As with tomatoes, the impact on lettuce and broccoli mortality appears to be confined to the period immediately following transplanting. Plant density at harvest was not significantly different from that at 5 weeks (table 3).

\section{Transplant biomass}

Tomato. Even in plots where mortality was low, tomato shoot and root weights were negatively affected by sudex. In the sudex shoot + root treatments in 1999, shoot weights of tomato transplants were reduced by $86 \%$ compared to the fallow control (table 1). In plots where sudex had been incorporated, tomato shoot weight was reduced by $44 \%$ even though there was no significant impact on plant mortality (table 1). Only plots containing sudex shoots + roots significantly reduced the shoot biomass for lettuce and broccoli (table 1). Similar results were obtained in 2000, with all sudex treatments producing less tomato shoot and root biomass than the control plots when transplants were set up to 36 days after shredding (table 4). Even at 67 days postshredding, the shoot and root weights of transplants set into plots containing sudex shoot + root material were significantly lower $(P \leq 0.05)$ than those in the fallow control (table 4).

Lettuce and broccoli. Lettuce and broccoli were less influenced by sudex than was tomato. At 21 days postshredding, both lettuce and broccoli produced shoots and roots with significantly less weight in all sudex treatments compared to the control (table 5). By 35 days, lettuce shoot weights were still significantly less than the control in all treatments, but broccoli shoot

TABLE 3. Mean number lettuce and broccoli plants per plot 5 weeks after transplant and at harvest, 2000

Days between sudex shredding and transplanting

21 Broccoli $\frac{35}{\text { Lettuce Broccoli }}$

\begin{tabular}{lcl} 
Treatment & Lettuce Broccoli Lettuce Broccol \\
\hline At 5 weeks & $\ldots \ldots \ldots \ldots$ no. plants $\ldots \ldots \ldots$
\end{tabular}

Shoots + roots $8.17 a^{*} \quad 8.17 a \quad 9.33 a \quad 9.83 a$

$\begin{array}{lllll}\text { Shoots } & 7.50 a & 8.17 a & 9.50 a & 9.50 a\end{array}$

$\begin{array}{lllll}\text { Roots } & 9.83 \mathrm{~b} & 9.50 \mathrm{~b} & 10.00 \mathrm{a} & 9.52 \mathrm{a}\end{array}$

$\begin{array}{lllll}\text { Incorporated } & 9.67 \mathrm{~b} & 9.67 \mathrm{~b} & 9.83 \mathrm{a} & 9.83 \mathrm{a}\end{array}$

$\begin{array}{lllll}\text { Control } & 10.00 \mathrm{~b} & 10.00 \mathrm{~b} & 10.00 \mathrm{a} & 9.67 \mathrm{a}\end{array}$

\begin{tabular}{lllll}
\hline At harvest & $\ldots \ldots \ldots$ & $\ldots$ & no. plants $\cdots \cdots \cdots$ \\
Shoots + roots & $8.17 a$ & $8.33 a$ & $9.83 a$ & $9.67 a$
\end{tabular}

Shoots + roots $8.17 \mathrm{a} \quad 8.33 \mathrm{a} \quad 9.83 \mathrm{a} \quad 9.67 \mathrm{a}$

$\begin{array}{lllll}\text { Shoots } & 7.50 a & 6.83 a & 9.50 a & 9.67 a\end{array}$

$\begin{array}{lllll}\text { Roots } & 9.83 \mathrm{~b} & 9.17 \mathrm{~b} & 9.83 \mathrm{a} & 9.50 \mathrm{a}\end{array}$

$\begin{array}{lllll}\text { Incorporated } & 9.67 \mathrm{~b} & 9.00 \mathrm{~b} & 9.83 \mathrm{a} & 10.00 \mathrm{a}\end{array}$

$\begin{array}{lllll}\text { Control } & 10.00 \mathrm{~b} & 9.83 \mathrm{~b} & 9.67 \mathrm{a} & 9.50 \mathrm{a}\end{array}$

* Means followed by the same letter(s) are not significantly different according to $L S D$ test, $P \leq 0.05$.

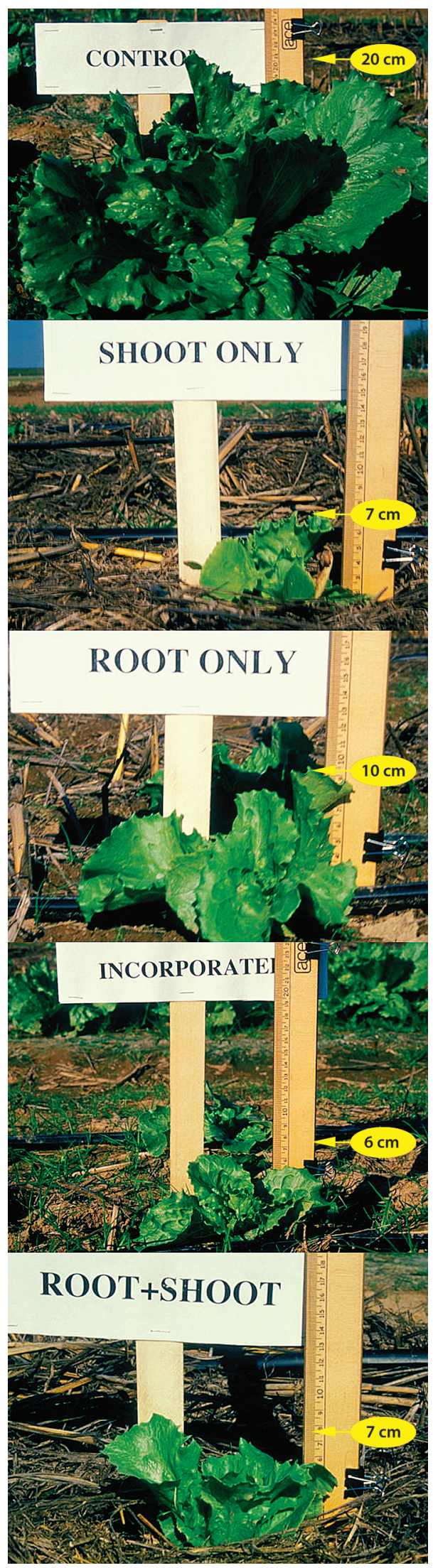

Lettuce was a bit more tolerant of sudex than tomato, but those set $\mathbf{2 1}$ days after sudex was cut were all significantly stunted. However, lettuce transplants set 35 days after sudex was cut did not suffer any yield impacts. 

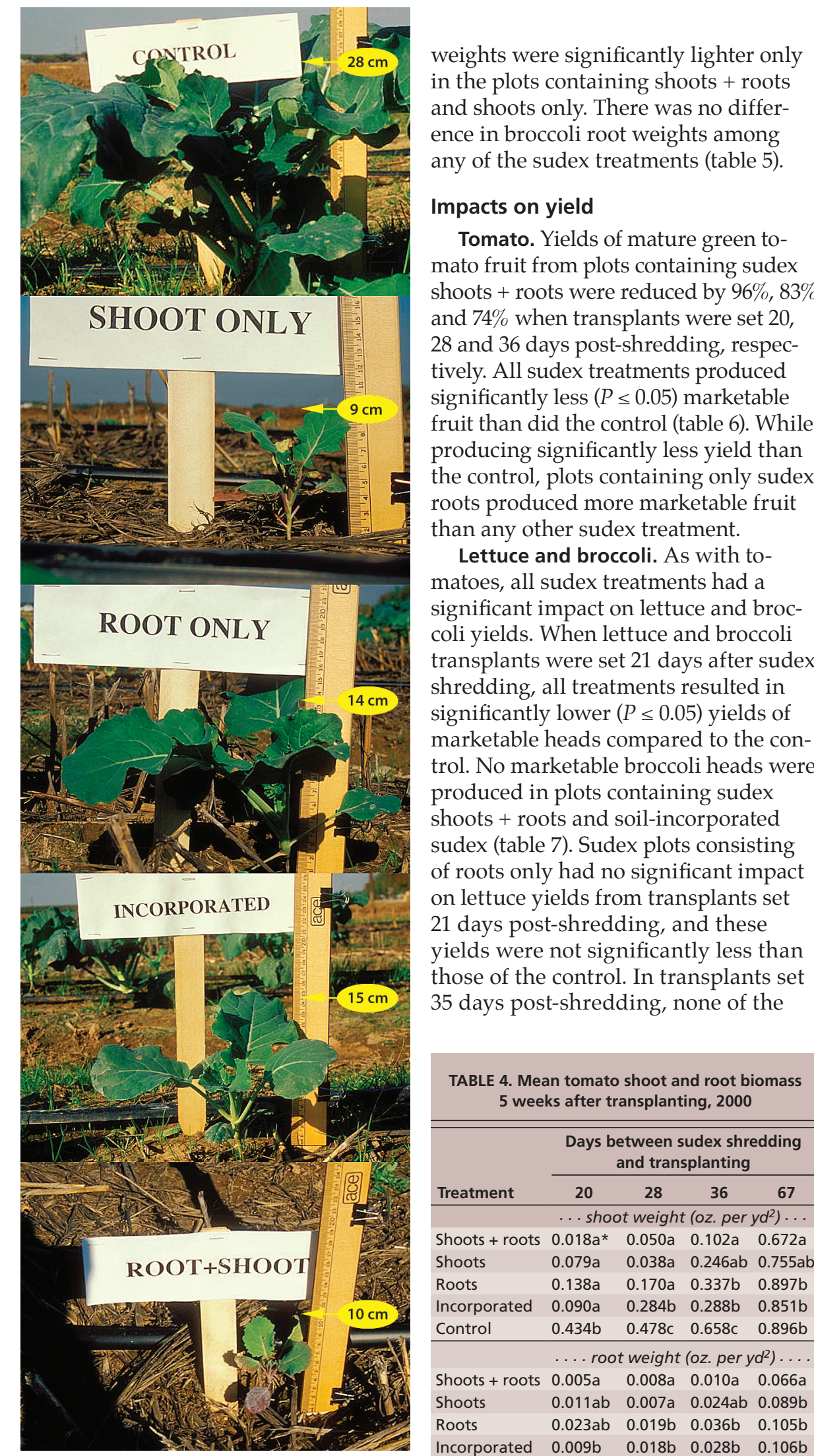

Broccoli transplanted 21 days after sudex was cut showed varying degrees of damage and yield loss, depending on the treatment. This effect continued with broccoli transplants set 35 days after sudex was cut. weights were significantly lighter only in the plots containing shoots + roots and shoots only. There was no difference in broccoli root weights among any of the sudex treatments (table 5).

\section{Impacts on yield}

Tomato. Yields of mature green tomato fruit from plots containing sudex shoots + roots were reduced by $96 \%, 83 \%$ and $74 \%$ when transplants were set 20 , 28 and 36 days post-shredding, respectively. All sudex treatments produced significantly less $(P \leq 0.05)$ marketable fruit than did the control (table 6). While producing significantly less yield than the control, plots containing only sudex roots produced more marketable fruit than any other sudex treatment.

Lettuce and broccoli. As with tomatoes, all sudex treatments had a significant impact on lettuce and broccoli yields. When lettuce and broccoli transplants were set 21 days after sudex shredding, all treatments resulted in significantly lower $(P \leq 0.05)$ yields of marketable heads compared to the control. No marketable broccoli heads were produced in plots containing sudex shoots + roots and soil-incorporated sudex (table 7). Sudex plots consisting of roots only had no significant impact on lettuce yields from transplants set 21 days post-shredding, and these 35 days post-shredding, none of the

\begin{tabular}{|c|c|c|c|c|}
\hline \multirow[b]{2}{*}{ Treatment } & \multicolumn{4}{|c|}{$\begin{array}{c}\text { Days between sudex shredding } \\
\text { and transplanting }\end{array}$} \\
\hline & 20 & 28 & 36 & 67 \\
\hline & \multicolumn{4}{|c|}{... shoot weight (oz. per $y d^{2}$ ). . . } \\
\hline Shoots + roots & $0.018 a *$ & $0.050 a$ & $0.102 a$ & $0.672 a$ \\
\hline Shoots & $0.079 a$ & $0.038 a$ & $0.246 a b$ & $0.755 \mathrm{ak}$ \\
\hline Roots & $0.138 a$ & $0.170 a$ & $0.337 \mathrm{~b}$ & $0.897 b$ \\
\hline Incorporated & $0.090 a$ & $0.284 b$ & $0.288 b$ & $0.851 b$ \\
\hline \multirow[t]{2}{*}{ Control } & $0.434 b$ & $0.478 c$ & $0.658 \mathrm{c}$ & $0.896 b$ \\
\hline & \multicolumn{4}{|c|}{... root weight (oz. per $\left.y d^{2}\right) \ldots$} \\
\hline Shoots + roots & $0.005 a$ & $0.008 a$ & $0.010 a$ & $0.066 a$ \\
\hline Shoots & $0.011 \mathrm{ab}$ & $0.007 a$ & $0.024 a b$ & $0.089 \mathrm{~b}$ \\
\hline Roots & $0.023 a b$ & $0.019 b$ & $0.036 b$ & $0.105 b$ \\
\hline Incorporated & $0.009 b$ & $0.018 b$ & $0.028 b$ & $0.106 b$ \\
\hline Control & $0.055 c$ & $0.034 c$ & $0.059 c$ & $0.093 b$ \\
\hline
\end{tabular}

* Means followed by the same letter(s) are not significantly different according to LSD test, $P \leq 0.05$. treatments had an influence on lettuce yields, but all treatments continued to cause a significant reduction $(P \leq 0.05)$ in broccoli yields.

\section{Sudex residue and transplants}

The allelopathic impacts of a previous sudex crop on tomato, lettuce and broccoli transplants were noticeable almost immediately after they were set. Within 3 to 5 days, transplants began showing evidence of phytotoxicity, injury to a plant caused by a chemical. Tomato plants became chlorotic (yellow) with older leaves becoming necrotic (showing areas of dead tissue). Lettuce leaves had marginal necrosis and broccoli leaves turned purple, indicating a phytotoxicity of some kind. Plants were stunted, and those that were most severely affected failed to produce any new growth and died.

The combination of sudex shoots + roots was the most consistent treatment in reducing transplant survival in all crops, followed by plots in which the sudex shoots + roots had been soilincorporated. Tomato transplants were more susceptible to sudex than broccoli or lettuce transplants. In tomato transplants set 36 days after sudex shredding, mortality remained significantly higher than in the control. In contrast, in broccoli and lettuce transplants set 35 days post-shredding, there was no difference in mortality among any of the sudex treatments and the control. In

\begin{tabular}{|c|c|c|c|c|}
\hline \multirow[b]{3}{*}{ Treatment } & \multicolumn{4}{|c|}{$\begin{array}{l}\text { Days between sudex shredding } \\
\text { and transplanting }\end{array}$} \\
\hline & \multicolumn{2}{|c|}{ Lettuce } & \multicolumn{2}{|c|}{ Broccoli } \\
\hline & 21 & 35 & 21 & 35 \\
\hline & \multicolumn{4}{|c|}{... shoot weight (oz. per $\left.y d^{2}\right) \ldots$} \\
\hline Shoots + roots & $0.041 a *$ & $0.076 a$ & $0.019 a$ & $0.031 a$ \\
\hline Shoots & $0.104 a b$ & $0.089 a$ & $0.019 a$ & $0.044 a$ \\
\hline Roots & $0.173 b$ & $0.140 b$ & $0.096 b$ & $0.079 b$ \\
\hline Incorporated & $0.085 a b$ & $0.146 b c$ & $0.042 \mathrm{ab}$ & $0.080 \mathrm{~b}$ \\
\hline \multirow[t]{2}{*}{ Control } & $0.410 \mathrm{c}$ & $0.172 c$ & $0.425 c$ & $0.088 \mathrm{~b}$ \\
\hline & \multicolumn{4}{|c|}{$\ldots$ root weight (oz. per $\left.y d^{2}\right) \ldots$} \\
\hline Shoots + roots & $0.061 a$ & $0.124 a$ & $0.023 a$ & $0.070 a$ \\
\hline Shoots & $0.066 a$ & $0.122 a$ & $0.028 a$ & $0.068 a$ \\
\hline Roots & $0.065 a$ & $0.118 a$ & $0.048 b$ & $0.054 a$ \\
\hline Incorporated & $0.048 a$ & $0.136 a b$ & $0.028 a$ & $0.063 a$ \\
\hline Control & $0.171 b$ & $0.169 b$ & $0.088 c$ & $0.093 a$ \\
\hline \multicolumn{5}{|c|}{$\begin{array}{l}\text { * Means followed by the same letter(s) are not significantly } \\
\text { different according to LSD test, } P \leq 0.05 \text {. }\end{array}$} \\
\hline
\end{tabular}




\begin{tabular}{|c|c|c|c|}
\hline \multicolumn{4}{|c|}{$\begin{array}{l}\text { TABLE 6. Mean yield of mature green tomato } \\
\text { fruit, } 2000\end{array}$} \\
\hline \multirow[b]{2}{*}{ Treatment } & \multicolumn{3}{|c|}{$\begin{array}{c}\text { Days between sudex shredding } \\
\text { and transplanting }\end{array}$} \\
\hline & 20 & 28 & 36 \\
\hline & \multicolumn{3}{|c|}{ mature green fruit (Ib per acre) } \\
\hline Shoots + roots & $1,721 a^{*}$ & $3,282 a$ & 5,923ab \\
\hline Shoots & $6,442 b c$ & $4,707 a$ & $9,990 \mathrm{ab}$ \\
\hline Roots & $8,305 c$ & $10,636 b$ & $11,396 b$ \\
\hline Incorporated & $3,684 a b$ & 3,351a & 4,989a \\
\hline Control & $18,240 d$ & $19,664 c$ & $22,577 c$ \\
\hline
\end{tabular}

all three crops, transplants set into plots of sudex-roots-only did not differ in mortality from the control. Fertilization was adequate to produce healthy, viable plants and we observed no indication of disease or insect activity that could account for the mortality. Transplant shock was not an issue since the affected plants never recovered.

Abdul-Baki (1998) reported that allelopathy was severe on tomato and muskmelon transplants set into mulches containing rye (Secale cereale L.) but that full recovery was attained 3 weeks after transplanting. Norsworthy and Meehan (2005) found that the leaf margins of tomato and bell pepper (Capsicum frutescens L.) transplants into soil amended with wild radish (Raphanus raphanistrum L.) residue were necrotic for 2 and 9 weeks, respectively, but that injury was transient and both eventually recovered. This clearly was not the case in our sudex experiments. Not only was there substantial transplant mortality, but also most of the surviving plants were severely stunted and failed to recover and produce yields comparable to the controls; the exception was lettuce set 35 days post-shredding. Similarly, Finney (2005) reported that when grown following a sudex cover crop, cabbage (Brassica oleracea var. capitata L.) had reduced head weights and increased time to maturity.

In our study, the impact of allelopathic chemicals was reduced as the

\begin{tabular}{|c|c|c|c|c|}
\hline \multirow[b]{4}{*}{ Treatment } & $\begin{array}{l}\text { lean yield } \\
\text { nd broccol }\end{array}$ & $\begin{array}{l}\text { of marke } \\
\text { li heads, }\end{array}$ & $\begin{array}{l}\text { etable let } \\
2000\end{array}$ & \\
\hline & \multicolumn{4}{|c|}{$\begin{array}{l}\text { Days between sudex shredding } \\
\text { and transplanting }\end{array}$} \\
\hline & \multicolumn{2}{|c|}{21} & \multicolumn{2}{|c|}{35} \\
\hline & Lettuce & Broccoli & Lettuce & Broccoli \\
\hline & \multicolumn{4}{|c|}{$\ldots$ fresh weight (lb per acre) ..... } \\
\hline Shoots + roots & $344 a^{*}$ & $0 a$ & $1,106 a$ & $112 a$ \\
\hline Shoots & $495 a$ & $134 a$ & $1,269 a$ & $221 a$ \\
\hline Roots & $1,611 \mathrm{bc}$ & $405 a$ & $833 a$ & $354 a$ \\
\hline Incorporated & 734ab & $0 a$ & $597 a$ & $239 a$ \\
\hline Control & $2,629 \mathrm{c}$ & $1,865 \mathrm{~b}$ & $1,780 a$ & $1,597 b$ \\
\hline
\end{tabular}

sudex residue aged, probably due to leaching. By 35 days post-shredding, there was no further increase in plant mortality for both broccoli and lettuce and no additional loss of yield for lettuce. Diab (2003) reported similar results on the germination of lettuce seed following the removal of allelochemicals from rye by leaching. Holmes and Mayberry (1996) found significantly fewer lettuce plants started from seed in sudangrass plots that had not been either leached by flooding or allowed to decompose for at least 22 days prior to planting. Our results were similar in that transplants set between 21 and 35 days post-shredding showed no increased mortality. This period involved several irrigations, which could have leached the active allelochemicals from the sudex and moved them beyond the vegetable root zone.

\section{Effects of allelochemicals}

Allelochemicals derived from sudex apparently affected transplant mortality and ultimately yields in all three crops. The active allelochemicals operating in this system were not determined, as this was outside of the scope of our field study. However, a number of inhibitory compounds have been identified from Sorghum spp. These compounds include prussic acid (Dover et al. 2004) and $p$-hydroxybenzoic acid, $p$-hydroxybenzaldehyde and dhurrin (Weston et al. 1989), the latter of which converts to cyanide. Seigler (2005) noted

\section{Not only was there substantial transplant mortality, but most of the surviving plants were severely stunted and failed to recover and produce yields comparable to the controls.}

that cyanide, derived from cyanogenic glycosides, may be responsible for the allelopathic activities of Sorghum spp., but that the active toxicants may actually be benzaldehyde or $p$-hydroxybenzaldehyde. However, in addition to its negative impact on animals, cyanide is also known to be detrimental to plants. Morita et al. (2005) reported that hydrogen cyanide inhibited both radicle and hypocotyl growth of lettuce seedlings.

Ben-Hammouda et al. (1995a) found that aqueous sorghum extracts contain five phenolic acids ( $p$-hydroxybenzoic, vanillic, syringic, $p$-coumaric and ferulic) that were all allelopathic to wheat. Another Sorghum spp.-derived compound that has been implicated is sorgoleone, a photosynthesis inhibitor that is a potent allelochemical (Czarnota et al. 2001; Geneve and Weston 1988; Weston et al. 1989). However, it is not likely that sorgoleone is the allelochemical responsible for plant mortality in our studies. Sorgoleone is produced by the root hairs and is secreted into the soil, and our studies showed that the root portion of the sudex plant was likely not responsible for the mortality: plant mortality in plots containing sudex roots only was not significantly different from that in the fallow control. But sorgoleone could have played a role in reducing shoot and root weights, leading to plant stunting; in all three crops, weights were significantly reduced in the sudex root-only plots for several weeks after transplanting. Also, while plant mortality was not affected in the sudex roots-only plots, plants were still injured as indicated by the significantly reduced yields.

Ben-Hammouda et al. (1995a) also found that water extracts of sorghum stems were the most inhibitory to wheat seedling growth, followed by extracts from leaves and roots. Similarly, in our studies, sudex shoots (including leaves), both on the surface and soilincorporated, appeared to be most toxic to all three vegetables studied. These sudex treatments had the greatest impact on both transplant mortality and vegetable shoot and root weights. Del Moral (1975) made the significant observation that allelopathy is seldom due to a single chemical, but rather to the interaction of similar compounds or, sometimes, unrelated compounds. 
He further states that bioassays of individual chemicals may lead to erroneous conclusions. We think that a number of allelochemicals are interacting to produce the toxic effect found with sudex and vegetable transplants, but further research is needed to elucidate the exact allelochemicals involved.

\section{Transplant recommendations}

None of the vegetables studied should be transplanted into a sudex cover crop that has been shredded unless an adequate time interval (6 to 8 weeks) is allowed and measures are taken to leach the active allelochemicals from the sudex residue. Flooding, sprinkling, surface drip or multiple precipitation events can accomplish leaching. It is apparently less risky to plant any of these vegetables into sudex stubble following removal of the crop for forage, silage or biomass, since these plots did not result in significant transplant mortality. However, there was sufficient injury and stunting to these transplants, with significantly less yield than those planted into fallow soil. Transplants of other vegetable crops may react the same way, so caution should be practiced. The same rule of thumb for a shredded sudex cover crop should also be followed for stubble that remains after the biomass has been removed. Care should also be taken that there is no sudex regrowth following final removal of the standing crop and setting transplants, as this will only add to the problem.

C.G. Summers is Entomologist, Department of Entomology, UC Davis; J.P. Mitchell is Extension Specialist, Department of Plant Sciences, UC Davis; T.S. Prather was Integrated Pest Management Weed Ecologist, UC Statewide IPM Program (currently Associate Professor and Extension Specialist, Department of Plant, Soil and Entomological Sciences, University of Idaho); and J.J. Stapleton is Integrated Pest Management Plant Pathologist and Coordinator, Natural Resources Program, UC Statewide IPM Program. All UC-affiliated authors are located at UC Kearney Agricultural Center, Parlier. We thank Albert Newton, Ryan Smith, Susan Mallek and Ravi Gill for technical assistance. We appreciate the assistance of Associate Editor Carol Lovatt, whose comments greatly improved the manuscript.

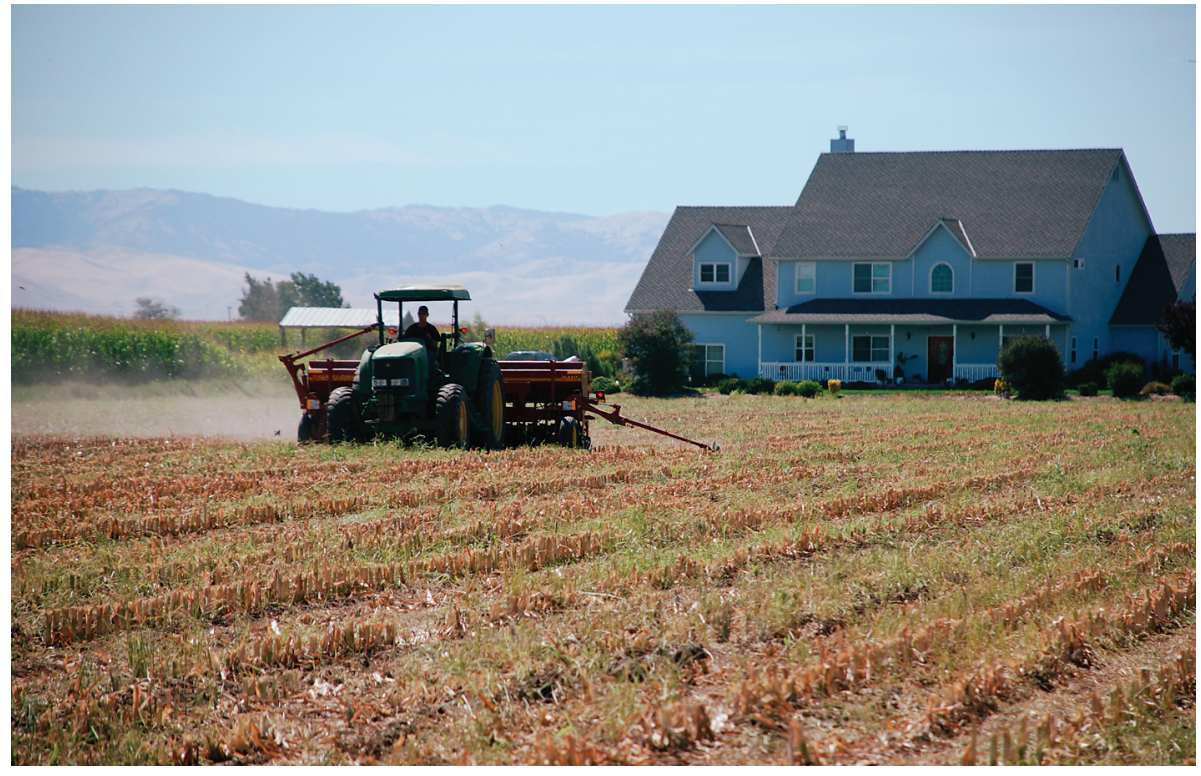

A time interval of 6 to 8 weeks, coupled with adequate irrigation or precipitation, can facilitate the leaching of allelochemicals from the soil, making it safe to plant the vegetables studied.

\section{References}

Abdul-Baki A. 1998. Soil management: The key to sustainability. UC Davis Vegetable Research and Information Center. 4 p. http://vric.ucdavis.edu/ news_and_events/bulletinboard/soilconf/key.pdf.

Ben-Hammouda M, Kremer RJ, Minor HC. 1995a. Phytotoxicity of extracts from sorghum plant components on wheat seedlings. Crop Sci 35:1652-6.

Ben-Hammouda M, Kremer RJ, Minor HC, Sarwar M 1995b. A chemical basis for differential allelopathic potential of sorghum hybrids on wheat. J Chem Ecol 21:775-86.

Chaudhry SM, Naseer Z, Alkraidees MS. 1997. Nutritive evaluation of poultry waste and Sudex grass silage for sheep. Asian-Austral J Anim Sci 10:79-85.

Czarnota MA, Paul R, Dayan FE, et al. 2001. Mode of action, localization of production, chemical nature and activity of sorgoleone: A potent PSII inhibitor in Sorghum spp. root exudates. Weed Tech 15:813-25.

Del Moral R. 1975. Allelopathy: A milestone monograph. Ecology 56:1231-3.

Diab N. 2003. Targeted mowing as a weed management method increasing allelopathy in rye (Secale cereale L.). Organic Farming Research Foundation. Santa Cruz, CA. 20 p. http://ofrf.org.

Dover K, Wang KH, McSorley R. 2004. Nematode management using sorghum and its relatives. IFAS University of Florida. http://edis.ifas.ufl.edu/IN531.

Einhellig FA, Souza IF. 1992. Phytotoxicity of sorgolone found in grain sorghum root exudates. J Chem Ecol 18:1-12.

Finney D. 2005. Sorghum-sudangrass grown as a cover crop for organic no-till vegetable production, and as a hay crop for the organic market. Organic Farming Research Foundation. Santa Cruz, CA. 19 p. http://ofrf.org.

Forney DR, Foy CL. 1985. Phytotoxicity of products from rhizospheres of a sorghum sudangrass hybrid (Sorghum bicolor x Sorghum sudanense). Weed Sci 33:597-604.
Frate CA. 2001. Overview of forages, other than alfalfa, in California: Current status and future trends. In: Proc 31st California Alfalfa and Forage Symposium, Dec. 12-13, 2001. Modesto, CA. p 109-12. UC Cooperative Extension, UC Davis. http://alfalfa.ucdavis.edu/+symposium/ proceedings/2001/01-109.pdf.

Geneve RL, Weston LA. 1988. Growth reduction of eastern redbud (Cercis canadensis L.) seedlings caused by interaction with a sorghum-sudangrass hybrid (Sudex). J Environ Hort 6:24-6.

Holmes GJ, Mayberry KS. 1996. Adverse effects of sudan grass residue on lettuce stand establishment. UC Cooperative Extension. Imperial County Ag Briefs.

Jackson L, Mayberry K, Koike S, et al. 1996. Iceberg Lettuce Production in California. UC ANR Pub 7215. Oakland, CA. 4 p.

Le Strange M, Mayberry KS, Koike ST, Valencia J. 1996. Broccoli Production in California. UC ANR Pub 7211. Oakland, CA. 3 p.

Le Strange M, Schrader WL, Hartz TK. 2000. Fresh Market Tomato Production in California. UC ANR Pub 8017. Oakland, CA. 8 p.

Morita S, Ito M, Harada J. 2005. Screening of an allelopathic potential in arbor species. Weed Biol Manage 5:26-30.

Norsworthy JK, Meehan JT. 2005. Wild radishamended soil effects of yellow nutsedge (Cyperus esculentus) interference with tomato and bell pepper. Weed Sci 53:77-83.

Seigler DS. 2005. Basic pathways for the origin of allelopathic compounds. In: Roger MJR, Pedrol N, González L (eds.). Allelopathy: A Physiological Process with Ecological Implications. Dordrecht, Netherlands: Springer. p 11-62.

Weston LA, Harmon R, Mueller S. 1989. Allelopathic potential of sorghum sudangrass hybrid (Sudex). J Chem Ecol 15:1855-65. 